Ercan, A.N. (2014). 8. sınıf Türkçe ders kitaplarındaki şiirlerin şekil, tema ve tür açılarından incelenmesi. Ana Dili Eğitimi Dergisi, 2(2), 15-27.

Ana Dili Eğitimi Dergisi
Journal of Mother Tongue Education
ADED - JOMTE
www.anadiliegitimi.com

\title{
8. Sınıf Türkçe Ders Kitaplarındaki Şiirlerin Şekil, Tema ve Tür Açılarından İncelenmesi
}

\author{
Aliye Nur Ercan ${ }^{*}$
}

\begin{abstract}
Özet
Öğrencilere anlama ve anlatma becerileri kazandırma, bu becerileri geliştirme ve dil bilgisi açısından onları bilgilendirme Türkçe dersinin temel amaçlarındandır. Öğretmenlerin başlıca materyali olan ders kitapları, bu amaçlara ulaşmada en önemli yardımcılardır. Türkçe ders kitapları sınıf seviyeleri göz önünde bulundurularak çeşitli metin türleri içerir. Çalışmanın esası olan 8. Sınıf Türkçe ders kitaplarında bulunması gereken metin türleri arasında, ilköğretim Türkçe dersi $(6,7,8$. sınıflar) öğretim programına göre şiir de yer almaktadır. Gerek biçimsel farklılığ gerekse duyguya hitap eden yönüyle şiir, diğer türlerden ayrılır. Bu çalışmanın genel amacl; 8 . sınıf Türkçe ders kitaplarındaki şiirleri şekil, tema ve tür açılarından incelemektir. Çalışmada, ele alınan yayınların ders kitaplarında okuma ve serbest okuma materyali olarak yer verilen şiirlerin yanı sıra dinleme metni olan şiirler de incelenmiştir. Doküman analizi ile gerçekleştirilen çalışmada, elde edilen veriler sınıflandırılıp yüzde ve frekansa dayalı şekil, tema ve tür bakımından değerlendirilmiştir.
\end{abstract}

Anahtar sözcükler: Türkçe ders kitabı, şiir, tema, tür.

Analysing the Poetry with Regards to Form, Theme and Genre in Turkish Textbooks for 8th Grade

\begin{abstract}
The main goals of Turkish lessons are provide students' understanding and telling skills, improving these skills and inform them in the terms of grammar. The textbooks, which are the main materials of all teachers, are the most important assistants to achive this goal. Turkısh textbooks include various text types by taking into consideration the grade levels. Among the text types that is necessary to include in the eighth grade Turkish textbooks, which are the basis of the study, poems are included according to the primary Turkish lesson $(6,7,8$. grades) teaching program. The poetry differs from the other types with the aspects of both its stylistic difference and sentimental. The general purpose of this study is analyze the poems, which are included in eighth grade Turkish textbooks, in terms of the form, theme and genre. In the study, as well as poems, which are exist as reading and independent reading material in the textbooks of the handeled editions, poems, which are listening texts, are analyzed. In the study, which is carried out with the document analiysis, obtained datas are classified and is evaluated based on the.percentage and frequency in terms of the form, theme and genre.
\end{abstract}

Keywords: Turkish textbook, poetry, theme, genre.

\footnotetext{
${ }^{*}$ Arş. Gör, Konya Necmettin Erbakan Üniversitesi, Ahmet Keleşoğlu Eğitim Fakültesi, Türkçe Eğitimi Bölümü. E-posta: ercanaliyenur@gmail.com
} 


\section{Giriş}

Dil, insanlar arasında anlaşmayı sağlayan en önemli unsurlardandır. Dilin etkili ve yerinde kullanımı sosyal hayat içinde bireylerin doğru iletişimi için önemlidir. Dilin, sosyal hayattaki önemi kadar eğitim ve öğretim hayatında da yeri büyüktür. Birey, dil edinimini ilk olarak aile ortamında kazanmaya başlar. Okul çağına gelindiğinde ise dil gelişiminin en önemli destekçisi Türkçe dersidir.

Türkçe dersinin kazanımlarını gerçekleştirmek için kullanılacak metinler ve bunların üzerinde yaptırılacak çalışmalar büyük önem arz etmektedir. Derslerde tercih edilecek metinler, "Kişiliğin oluşumunda önemli bir yeri olan ulusal bilinci ve coşkuyu kazanma, olayları neden-sonuç ilişkisi içinde ele alarak yargılama gücünü geliştirme, dil becerisini yerleştirme, yazma ve okuma etkinliğiyle imgelem gücünü besleme, güzel ve etkili anlatım” (Özdemir, 1983: 27) gibi amaçlara ulaşılabilecek nitelikte olmalıdır. Haftalık ders programında en fazla ders saatine sahip olan Türkçe dersinin temel amacı ise öğrencilere anlama (okuma ve dinleme) ve anlatma (konuşma ve yazma) becerileri kazandırmak ve bu becerileri geliştirmektir. Bu amacı gerçekleştirmek için çeşitli materyaller kullanılabilir.

Öğretmenin ilk materyali ders kitaplarıdır. Programda yer alan kazanımlarla tutarlı konuların yer aldığı bu kitaplar öğrencilere bilgi, beceri ve alışkanlıkların kazandırmasını hedefleyen temel kaynak niteliği taşırlar. Kitaplar, öğrencilerin gelişim düzeyleri göz önünde bulundurularak sınıflara göre çeşitli sayı ve türlerde metinler içerirler. Illköğretim Türkçe dersi öğretim programı ve kılavuzunda (1-5. sınıflar) şiir ile ilgili "Dinlediği şiirin ana duygusunu belirler", "Bildiği şiirleri topluluk önünde okur" gibi kazanımlara rastlanırken ilköğretim Türkçe dersi $(6,7,8$. sınıflar) öğretim programında, sınıflarda yer verilmesi gereken türler (2006: 57) konu edilir ve her üç sınıfta da şiir metinlerinin olması gerektiğine değinilir. Programda ders kitaplarındaki altı temadan en az dördünde şiir metni bulunması gerektiği hususu ayrıca dikkat çekmektedir.

Zengin bir ahenk unsuru olan şiir, "Gerek içerik, öz, gerekse söze dönüştürme, sunuluş açısından özgün, etkilemeye duygulandırmaya yönelik, yaratı niteliği taşıyan bir söz sanatı ürünü" (Aksan, 1999: 8) olarak tanımlanabilir.

Şiir ile öğrencilerin tüm öğrenme alanlarındaki kazanımları edinmesi sağlanabilir. Şiir metinleri öğrencilere estetik bir bakış açısı kazandırmada ve çeşitli ahenk unsurları içermesi ile ritim duygusu oluşturmada da oldukça etkilidir. Özbay da çalışmasında bu görüşü destekleyen şu ifadeye yer vermiştir: "Okuma sürecinde şiirlerin kullanımı öğrencilerin okuma becerilerinde ritim, tonlama ve duraklamayı kazanmalarında yardımcı olur" (2009: 25). Öğrenciler şiir metinlerini hafızalarına kolaylıkla yerleştirebilir. Aldıkları başarı tadıyla da öğrenmeye karşı ilgi ve istekleri artar. 


\section{Sınıf Türkçe Ders Kitaplarındaki Şiirlerin Şekil, Tema ve Tür Açılarından İncelenmesi}

Metin türlerinin sınıflandırılmasında olaya ya da düşünceye dayalı türlerin dışında bağımsız bir yer teşkil eden şiir, Cemiloğlu (2001: 24)'nun ve Ünalan (2001: 157)'ın tasniflerine göre duyguya dayalı türler içerisinde bulunur.

Şiir dili, düz yazı metinlerinin dilinden oldukça farklıdır. Şiirler, Türkçenin güzelliklerini duygulu ve coşkulu bir şekilde kolaylıkla ifade edebilirler. "Şiir duygulara hitap eden, orada kök salıp yeşeren, meyvesini hayallerle süsleyip, ahenkle sergileyen bir sanattır. Bu sanatın araç ve amaç olarak kullanımı, diğer edebî türlerden farklı ve özel bir yere sahiptir" (Yalçın ve Aytaş, 2005: 307). Bunun için diğer türlerden ayrı şekilde ele alınmalıdır. Kitaplarda söz konusu edilen şiir metinlerini kısaltmak ya da eksiltmek anlamda ve ahenkte bozulmalara sebep olabilir. Şiirlerin bütün hâlinde alınması esastır. Bu durum Türkçe dersi $(6,7,8$. sınıflar) öğretim programında (2006: 56) da açıkça ifade edilmiştir.

Şiir bir edebî eser olarak ele alındığında, işlediği konu, biçiminden daha önde gelmez. Bu durum kaynaklarda "Şiirin yüzey yapısında yer alan bir unsur olan konu, genel ve evrensel nitelikli nesnel olgular, durumlar, olaylar ve meselelerdir. Konular belli bir millete ve ferde ait değil, tüm insanlığın ortak malıdır. Pek çok şair, aynı konuyu işleyebilir. Sanat eseri bu genel unsuru ele alıp kendi dünyasında öznelleştirir. Konu, bir bakıma şiirin üretilmesinde bir çıkış noktasıdır. Konu, amaç değil araçtır. Şiirin değeri konuyla değil, konuyu işleyiş biçimiyle ölçülür" (Çetin, 2003: 15-16) şeklinde ifade edilmiştir. Ancak, Türkçe ders kitaplarında yer alan şiirler, öğrencilere bu türden zevk almalarını sağlamanın yanında muhtevası ile öğretimlerine de katkıda bulunacaktır. Şiirler kitaplarda didaktik, epik, lirik, pastoral ya da satirik türlerde yer alırken örneğin Atatürk ve vatan sevgisi, millet olma bilinci, insan sevgisi, toplumda yaşatılan gelenek ve görenekler, doğa sevgisi gibi öğretiler de şiir metinleriyle öğrenciye daha kolay, kalıcı ve zevkli bir şekilde verilebilir.

Öğrenciler derste karşılaştığı şiir türüyle okuduğu/dinlediği metni anlama ve çözümleme, söz varlığını zenginleştirme gibi genel kazanımlara sahip olabilecekleri gibi farklı beceri alanlarında da ek kazanımlar elde ederler. Illköğretim Türkçe dersi $(6,7$, 8. sınıflar) öğretim programında şiir metinleriyle ilgili kazanımlar şu şekilde sıralanmıştır:

Okuma becerisi için;

\footnotetext{
* Sözün ezgisine dikkat ederek okur.

* Metnin türüyle ilgili özelikleri kavrar.

* Metindeki söz sanatlarııın anlatıma olan katkısını fark eder.

* Şiir dilinin farklılı̆ını ayırt eder.

* Şiirin kendisinde uyandırdığı duyguları ifade eder.
} 
* Metnin şairi hakkında bilgi edinir.

* Şiir ezberler, şiir dinletileri düzenler, ezberlediği şiirleri uygun ortamlarda okur.

Dinleme becerisi için;

* Şiir dilinin farklılığını ayırt eder.

* Şiirin kendisinde uyandırdığı duyguları ifade eder.

* Şiir, türkü, şarkı türlerinde metinler ezberler.

* Şiir, hikâye, masal dinletilerine katılır.

Konuşma becerisi için;

* Uygun yerlerde vurgu, tonlama ve duraklama yapar.

Yazma becerisi için;

* Şiir yazar.

* Şiir defteri tutar.

* Beğendiği sözleri, metinleri ve şiirleri derler.

Bunların yanı sıra Türkçe dersi, öğrencilerin şiir okumaktan zevk almalarını sağlarken onlara “...edebî değer taşıyan şiirleri, bu şiirlerdeki düşünce ve duygu özelliklerini yansıtacak biçimde yüksek sesle okuma becerisi kazandırma" (Kavcar, Oğuzkan ve Sever, 1995: 45) hedefini de gerçekleştirmektedir.

Dört dil becerisinde de kazanımları bulunan şiir metinleri için ilköğretim Türkçe dersi $(6,7,8$. sınıflar) öğretim programında (2006: 56) "Okuma Metinlerinde Bulunması Gereken Özellikler" başlığı altında "Şiir türündeki metinler öğrenci seviyesine uygun, şiir dilinin özelliklerini yansıtan, söz varlığını zenginleştiren, türünün güzel örneklerinden seçilmelidir" ve "Şairlerin yalnızca edebî yönlerini ön plana çıkarmalıdır" gibi ifadeler mevcuttur.

Programda da değinildiği gibi şiirin dil kullanımındaki zenginliği yansıtması için belirgin bazı özellikleri içermesi gerekmektedir. Bu nitelikleri şu şekilde sıralamak mümkündür:

“* Kafiyeler -eğer varsa- belirli olmalı ve birbirlerine yakın mısraların sonlarında bulunmalıdır.

* Düşünceler açık olarak ve bir beyit veya dörtlük (kıta) sınırları içinde anlatılmalıdır.

* Tasvirler yalın ve kesin olmalıdır.

* Benzetme, istiare, mecaz gibi edebî sanatlara ölçülü bir şekilde yer verilmelidir. 


\section{Sınıf Türkçe Ders Kitaplarındaki Şiirlerin Şekil, Tema ve Tür Açılarından İncelenmesi}

* Hayal ve duygular çocukların yaşantılarıyla ilgili olmalı, bu unsurlarla olaylar arasında sıkı bir bağlantı kurulmalıdır.

* Mısralar kısa, cümle düzen doğal ve seçilen sözcükler sade olmalıdır.

* Tam ve yarım kafiyelerden, ölçüden ve bazı mısraların tekrarından yararlanarak ahenk zenginliği sağlanmalıdır.

* Konu -yaşama sevinci, aile sevgisi, doğa yurt ve ulus sevgisi, güzellik duygusu gibiolumlu duygu ve davranışları kazandırıcı, geliştirici ve pekiştirici bir nitelik taşımalıdı" (Oğuzkan, 2010: 266). Bu nitelikleri taşıyan şiir metinlerinin öğrencilere daha cazip geleceği ve fayda sağlayacağı açıktır.

\section{Problem Durumu}

Şiirlerin gerek biçim gerekse muhteva özellikleriyle birçok edebî türden ayrıldığı görülür. Özündeki ahenk ve ritim, ona estetik bir yön kazandırmıştır. Dili, bir ezgi gibi akılda kalıcı ve dinleyenin ya da okuyanın üzerinde etki bırakıı bir özelliğe sahiptir. Şiir her yaştan bireye hitap edebilen ayrıcalıklı bir türdür. $O$, yüzyıllardır farklı biçim ve içerikleriyle her dönemde etkisini sürdürmüştür.

Şiirin öğrencilere ana dili bilinci kazandırmada etkisi büyüktür. İçeriğindeki imajlar ve motifler kimi zaman renkli bir tablo şıklığında gözlerde canlanırken kimi zaman da hayal gücünü zorlayıcı bir şekil alıp bireyleri farklı hülyalara daldırır.

Dil kullanımının zenginleştirilmesi ve geliştirilmesi için öğrencileri şiir metinleriyle karşılaştırmak gerekir. Bu amaçla Türkçe derslerinin başlıca materyallerinden olan ders kitapları farklı biçimlerde ve konularda şiirler içerir. Olaya ve bilgiye dayalı türlerden ayrılarak insanların duygularına seslenen şiir metinleri de en az diğer metin türleri kadar kitaplarda yer almalıdır. Böylelikle öğrenciler farklı biçim ve türleriyle karşılaşma imkânı bulacakları şiiri, daha rahat ve doğru şekilde anlayıp anlamlandıracaklardır.

Türkçe ders kitaplarında yer verilecek şiirler, öğrenci seviye ve ilgisine uygun, şiir dilinin özelliklerini iyi yansıtan ve türünü iyi temsil eden örneklerinden seçilirse öğrencilerde dil bilinci oluşturur ve onların gerek duyuşsal ve gerekse düşünsel gelişimlerine katkı sağlar. Bu faydaları göz önüne alınarak ders kitaplarındaki şiir metinlerinin üzerinde önemle durulması ve incelemeler yapılması beklenir.

Yukarıda belirtilenler de göz önüne alınarak bu çalışmanın problem cümlesi "8. sınıf Türkçe ders kitaplarındaki şiirlerin şekil, tema ve tür açılarından dağııımı nasıldır?" şeklinde oluşturulmuştur. Bu problem durumuna bağlı olarak çalışmanın alt problemleri aşağıdaki şekilde belirlenmiştir:

1) 8. Sınıf Türkçe ders kitaplarında şiir metinlerine ne sıklıkta yer verilmiştir? 
2) 8. Sınıf Türkçe ders kitaplarında yer alan şiir metinleri biçimsel açıdan nasıldır?

3) 8. Sınıf Türkçe ders kitaplarındaki şiirlerin temalara göre dağıımı, tema açısından uygun mudur?

4) 8. Sınıf Türkçe ders kitaplarında en çok tercih edilen şiir türü hangisidir?

\section{Çalışmanın Amacı ve Önemi}

Çalışmanın genel amacı; 8. Sınıf Türkçe ders kitaplarında yer alan şiir metinlerinin şekil, tema ve türlerinin tespit edilmesidir.

Bir metin türünün kavratılabilmesi için öğrencileri o türün özelliklerini iyi yansıtan, güzel ve dikkat çekici örnekleriyle karşılaştırmak gerekir. Aksi halde eksik ve yanlı̧̧ öğrenmeler kaçınılmaz olur. Farklı duygulara hitap edebilen şiir metinlerinin de ders kitaplarında çeşitli biçim ve türlerde, etkin örnekleriyle var olması gerekir.

Bu çalışma halen kullanılmakta olan 8. sınıf Türkçe ders kitaplarında yer alan şiirlerin, bu metin türünü öğrencilerin kavrayabilecekleri yeterlilik ve çeşitlilikte niteliklere sahip olup olmadığını ortaya koymak amacıyla gerçekleştirilmekte ve bu anlamda önemli görülmektedir.

\section{Sınırlılıklar}

Şiirler derlenirken 8.sınıf Türkçe derslerinde kullanılan Bisiklet, Enderun, Koza ve Millî Eğitim yayınlarına ait ders kitapları ele alınmıştır. Çalışma ismi geçen dört yayınevinin ders kitaplarında bulunan toplamda 23 farklı şiir ile sınırlıdır.

\section{Yöntem}

\section{İncelenen Türkçe Ders Kitapları}

Çalışmanın evrenini 8.sınıf Türkçe ders kitaplarındaki şiirler oluşturmaktadır. Örneklem olarak 2652 sayılı Tebliğler Dergisi'nde 2012-2013 eğitim-öğretim yılında 8. sınıflarda okutulmak için belirlenen 15 farklı yayınevince hazırlanan Türkçe ders kitaplarından Bisiklet, Enderun, Koza ve Millî Eğitim yayınevlerine ait kitaplardaki şiirler ele alınmıştır. Yayınların seçiminde tesadüfi örneklem alma yoluna gidilmiştir. Çalışmada ders kitaplarında okuma ve serbest okuma metni olarak yer alan şiirler üzerinde durulmuş; daha zengin bulgular elde edebilmek adına öğretmen kılavuz kitaplarında bulunan dinleme metinleri de kapsama dâhil edilmiştir. "Milli Kültür" temasındaki bir şiirin üç, "Atatürk" ve "Toplum Hayatı" temalarındaki birer şiirin iki farklı yayınevinin kitabında bulunması göz önüne alınarak örneklemin 23 farklı şiirden oluştuğu söylenebilir. Şiirlerin temaları kılavuz kitaplardan yararlanılarak tespit edilmiştir. 


\section{Sınıf Türkçe Ders Kitaplarındaki Şiirlerin Şekil, Tema ve Tür Açılarından İncelenmesi}

\section{Veri Toplama Modeli}

Çalışmada nitel araştırma yöntemlerinden doküman analizi yöntemi tercih edilmiştir. “Doküman incelemesi, araştırılması hedeflenen olgu veya olgular hakkında bilgi içeren yazılı materyallerin analizini kapsar. Geleneksel olarak doküman incelemesi, tarihçilerin, antropologların ve dilbilimcilerin kullandığı bir yöntem olarak bilinir" (Yıldırım ve Şimşek, 2011: 187).

\section{Verilerin Analizi}

Elde edilen veriler temaları ve türleri göz önünde bulundurularak kategorik olarak sınıflandırılmış, verilerin yüzde ve frekans analizleri yapılmıştır.

\section{Bulgular ve Yorum}

$\mathrm{Bu}$ bölümde çalışma kapsamında elde edilen bulgular, çalışmanın alt problemleri çerçevesinde sırasıyla sunulmuş ve yorumlanmıştır.

“8. Sınıf Türkçe ders kitaplarında şiir metinlerine ne sıklıkta yer verilmiştir?” alt problemine yönelik elde edilen bulgular Tablo 1'de sunulmuştur:

Tablo 1: Şiirlerin Yayınevlerine Göre Dağılımı

\begin{tabular}{lcccc}
\hline & Bisiklet & Enderun & Koza & Millî Ĕgitim \\
\hline Toplam Metin Sayısı & 37 & 43 & 36 & 37 \\
Şiir Metni Sayısı & 5 & 10 & 9 & 3 \\
Yüzde \% & 13,5 & 23,2 & 25 & 8,1 \\
\hline
\end{tabular}

Tablo 1'e göre serbest okuma metinleri de dâhil edilerek Millî Eğitim ve Bisiklet yayınlarının toplamda 37'şer, Enderun yayınlarının 43 ve Koza yayınlarının 36 metin içerdiği tespit edilmiştir. Kitaplarda bulunan metin türleri arasında şiir metinlerinin yerini belirlemek amacıyla yapılan analizlerle Milî Eğitim yayınlarının 3/37 (\%8,1), Bisiklet yayınlarının 5/37 (\%13,5), Enderun yayınlarının 10/43 $(\% 23,2)$ ve Koza yayınlarının 9/36 (\%25) oranlarında şiir metni içerdiği sonucuna ulaşılmıştır. Sonuca göre, en çok şiir metni içeren yayının Koza, en az şiir metni içeren yayının ise Millî Eğitim yayınları olduğu belirlenmiştir.

Çalışmanın "8. sınıf Türkçe ders kitaplarında yer alan şiir metinleri biçimsel açıdan nasıldır?” alt problemine ilişkin bulgularda, kitaplarda yer alan 23 şiirin 14'ünün serbest nazım ile yazılmış iken 9 tanesinin üçlük, dörtlük, beşlik ya da altılık birimler hâlinde yazılmış olduğu göze çarpmaktadır. Şiirlerin ölçüleri incelendiğinde, kitaplarda hem serbest ölçü hem de hece ölçüsü ile yazılmış şiirler tespit edilmiştir. 
Çocukların sevdikleri şiirler araştırmalara konu olmuş ve Kutiper (1985) çalışmasında 7, 8, 9. sınıf öğrencileri tarafından tercih edilen şiirleri: uyaklı, haiku (üç mısradan oluşan Japon şiiri) ve serbest şiir olarak belirlemiştir (Akt.Akyol, 2006). Ayrıca "Çocuk şiirinde serbest şiir örneklerine temel eğitimin birinci basamağında 4. sınıftan itibaren yer vermek yerinde olacaktır" (Yalçın ve Aytaş, 2005: 211) görüşü doğrultusunda da serbest nazım örneklerinin ders kitaplarında da yer alması uygun olmuştur. Bu durum şiirin sadece eşit sayıda hece ya da mısra birliklerinden oluşmuş metinler olmadığı bilgisinin öğrenciye kazandırılması açısından yararlı olacaktır. Kitaplarda bu amaca yönelik şiir örnekleri tespit edilmiştir:

"Bu Sabah Hava Berrak" (Cahit Sıtkı Tarancı)

"Nutuk" (Turgut Uyar)

Şiirin biçimsel özellikleri verilecek çok sayıda doğru örnekle öğrenciye kavratılmalıdır. Ünalan da eserinde bu görüşü destekleyen "Dize, kafiye, beyit, dörtlük, nazım birimi, kafiye dizilişi gibi terimleri sezdirme ve keşfettirme yoluyla öğrencinin bulmasını sağlamak en uygun yoldur" (2001: 169) ifadesini kullanmıştır. Kitaplarda serbest şiirin yanı sıra dörtlükler ya da bentler hâlinde oluşturulmuş ve hece ölçüsüyle yazılmış olan şiirler mevcuttur:

"Kütüphane" (Mustafa Nihat Malkoç)

"Rıhtımda Uyuyan Gemi" (Ahmet Hamdi Tanpınar)

Az sayıda şiir üzerinde ise kafiye-redif çalışmasının yapılabileceği gözlenmiştir:

"Şehrin Üstünden Geçen Bulutlar" (Ahmet Muhip Dıranas)

“Dostlar Beni Hatırlasın” (Aşık Veysel Şatıroğlu)

Kitaplarda benzetme, kişileştirme, tekrir, mecaz gibi şiire güzellik ve ahenk veren söz sanatlarının öğrenciye kavratılmasında kullanılabilecek örnekler de bulunmaktadır:

"Doğa Dedi Ki" (Sabahattin Kudret Aksal)

"Türküler Dolusu" (Bedri Rahmi Eyuboğlu)

Ele alınan dört yayın "8. Sınıf Türkçe ders kitaplarındaki şiirlerin temalara göre dağııımı, tema açısından uygun mudur?" alt problemine yönelik incelendiğinde kitaplardaki tema sayısının eşit ve toplamda altı tane olduğu görülmüştür. Tablo 2'de tema isimleri de verilerek bu durum netleştirilmiştir. 
Tablo 2: 8. Sinıf Ders Kitaplarındaki Temalar

\begin{tabular}{lcccc}
\hline Yayınlar & Bisiklet & Enderun & Koza & Millî Eğitim \\
\hline 1.Tema & Duygular & Okuma Kültürü & Kişisel Gelişim & Zaman ve Mekan \\
2.Tema & Atatürk & Atatürk & Atatürk & Atatürk \\
3.Tema & Doğa ve Evren & Sevgi & Millî Kültür & Millî Kültür \\
4.Tema & Toplum Hayatı & Millî Kültürümüz & Toplum Hayatı & Toplum Hayatı \\
5.Tema & iletişim & Doğa ve Evren & Duygular & Bilim ve Teknoloji \\
6.Tema & Zaman ve Mekan & Toplum Hayatı & Doğa ve Evren & Kişisel Gelişim \\
\hline
\end{tabular}

Tablo 2 değerlendirildiğinde, kitaplarda yer verilen temaların genel olarak benzemekle birlikte dört yayınevinde toplamda 11 farklı temanın yer aldığı görülmüştür. Alfabetik olarak sıralanan bu temalar şu şekilde isimlendirilmiştir: Atatürk, Bilim ve Teknoloji, Doğa ve Evren, Duygular, Iletişim, Kişisel Gelişim, Milli Kültür, Okuma Kültürü, Sevgi, Toplum Hayatı ve Zaman ve Mekan. Adı geçen on bir temadan dokuzunda şiir metinlerine rastlanırken "Bilim ve Teknoloji” ve "iletişim" temalarında şiir örneklerine yer verilmemiştir. Farklı metin türleriyle öğrenciye kavratılmak istenen bu temalarda şiir türüne hiç yer verilmemiş olması dikkat çekicidir.

Tablo 3: Şiirlerin Temalara Göre Dağııımı

\begin{tabular}{|c|c|c|c|c|c|c|c|c|c|c|c|c|}
\hline \multirow[t]{2}{*}{ TEMALAR } & \multicolumn{3}{|c|}{ Bisiklet } & \multicolumn{3}{|c|}{ Enderun } & \multicolumn{3}{|c|}{ Koza } & \multicolumn{3}{|c|}{ Millî Eğitim } \\
\hline & 0 & D & S.O & 0 & D & S.O & 0 & $\mathrm{D}$ & S.O & 0 & D & S.O \\
\hline Atatürk & & & $x$ & $x$ & & $x$ & $x$ & & $x$ & & & \\
\hline Doğa ve Evren & $x$ & & & $x$ & & & $x$ & & & & & \\
\hline Duygular & & $x$ & & & & & & $x$ & $x$ & & & \\
\hline Kişisel Gelişim & & & & & & & $x$ & & & & & \\
\hline Milli Kültür & & & & $x$ & & & $x$ & & & & $x$ & \\
\hline Okuma Kültürü & & & & & $x$ & $x$ & & & & & & \\
\hline Sevgi & & & & $x$ & $x$ & $x$ & & & & & & \\
\hline Toplum Hayatı & $x$ & & & $x$ & & & & $x$ & $x$ & & & \\
\hline Zaman ve Mekân & & $\mathrm{x}$ & & & & & & & & $\mathrm{x}$ & & $\mathrm{x}$ \\
\hline
\end{tabular}

Tablo 3'e göre, şiirlerin 12'sinin okuma, 7'sinin dinleme metni olduğu görülmektedir. 8 şiirin ise serbest okuma metni olarak çeşitli temaları desteklemek için tercih edilmiş olduğu söylenebilir. Böylelikle kitaplardaki şiirlerin 20'sinin okuma, 7'sinin dinleme becerisini geliştirmeye yönelik materyal olarak kullanılabileceği belirlenmiştir. Şiir metinlerinin vurgu ve tonlamalarına dikkat ederek ve uygun yerlerde duraklamalar yaparak okunması onları daha anlamlı ve estetik kılacaktır. Bu 
sebeple şiirin müzikalitesini de öğrencilere fark ettirebilmek için dinleme metinlerinde daha çok şiir tercih edilebilir.

Türkçe dersi $(6,7,8$. sınıflar) öğretim programıyla kitaplarda altı temadan en az dördünde şiir metinlerine yer verilmesi gerektiği belirlenmiştir. Tabloya göre, Millî eğitim yayınlarında 2, Bisiklet yayınlarında 5, Enderun ve Koza yayınlarında ise 6'şar temada şiir metni bulunmaktadır. Buna göre Millî eğitim yayınlarında şiir metinlerini artırma yoluna gidilmesi düşünülebilir.

8. sınıf Türkçe ders kitaplarında yer alan şiirler, temalara göre dağılımları göz önüne alınarak şairleriyle birlikte Tablo 4'te belirtilmiştir:

Tablo 4: 8.Sınıf Türkçe Ders Kitaplarındaki Şiirler

\begin{tabular}{|c|c|c|c|c|c|}
\hline Temalar & Şiirler & Bisiklet & Enderun & Koza & $\begin{array}{l}\text { Millî } \\
\text { Eğitim }\end{array}$ \\
\hline \multirow{3}{*}{ Atatürk } & Atatürk'ten Son Mektup (H. Yağcıoğlu) & $x$ & & $x$ & \\
\hline & Atatürk Kurtuluş Savaşında (C. Külebi) & & $x$ & & \\
\hline & Nutuk (T. Uyar) & & $\mathrm{x}$ & $x$ & \\
\hline \multirow{3}{*}{$\begin{array}{l}\text { Doğa } \\
\text { Evren }\end{array}$} & Atatürk Bir Çıkıştır, Varış Değil (O. Asena) & & & & \\
\hline & Doğa Dedi Ki (S.K. Aksal) & $\mathrm{X}$ & & & \\
\hline & Yedigöller'de Sonbahar (Ü.Y. Oğuzcan) & & $x$ & $x$ & \\
\hline \multirow{4}{*}{ Duygular } & $\begin{array}{l}\text { Şehrin Üstünden Geçen Bulutlar (A.M. } \\
\text { Dıranas) }\end{array}$ & & & & \\
\hline & Gün Olur (O.V. Kanık) & $x$ & & $x$ & \\
\hline & Rıhtımda Uyuyan Gemi (A.H. Tanpınar) & & & $\mathrm{X}$ & \\
\hline & İnsanla Güzel (í. Geçer) & & & $\mathrm{x}$ & \\
\hline $\begin{array}{l}\text { Kişisel } \\
\text { Gelişim }\end{array}$ & Bu Sabah Hava Berrak (C.S. Tarancı) & & & $\mathrm{x}$ & \\
\hline $\begin{array}{l}\text { Milli } \\
\text { Kültür }\end{array}$ & Türküler Dolusu (B.R. Eyuboğlu) & & $\mathrm{x}$ & & $x$ \\
\hline \multirow{3}{*}{$\begin{array}{l}\text { Okuma } \\
\text { Kültürü }\end{array}$} & Kütüphane (M.N. Malkoç) & & $\mathrm{x}$ & & \\
\hline & Çocuk Kitap (F.H. Dağlarca) & & $x$ & & \\
\hline & Ellinci Yıl Türküsü (A. İnal) & & $\mathrm{X}$ & & \\
\hline \multirow[t]{2}{*}{ Sevgi } & Sevgi (ì. Minnetoğlu) & & $x$ & & \\
\hline & Türkçe Katında Yaşamak (F.H. Dağlarca) & & $x$ & & \\
\hline \multirow{3}{*}{$\begin{array}{l}\text { Toplum } \\
\text { Hayatı }\end{array}$} & Birlikte (M. Salihoğlu) & $\mathrm{x}$ & $x$ & $x$ & \\
\hline & Dostlar Beni Hatırlasın (A.V. Şatıroğlu) & & & $\mathrm{x}$ & \\
\hline & Dönen Tekerlek (C.A. Kansu) & & & & \\
\hline \multirow{3}{*}{$\begin{array}{l}\text { Zaman ve } \\
\text { Mekan }\end{array}$} & Geçmiş Zaman Şiirleri (B.B. Tokel) & & & & $\mathrm{x}$ \\
\hline & İstanbul'u Dinliyorum (O.V. Kanık) & & & & $x$ \\
\hline & Evim (Y.Z. Ortaç) & $x$ & & & \\
\hline
\end{tabular}




\section{Sınıf Türkçe Ders Kitaplarındaki Şiirlerin Şekil, Tema ve Tür Açılarından İncelenmesi}

Tablo 4 incelendiğinde, "Milli Kültür" temasında üç farklı yayının (Enderun, Koza ve Millî Eğitim Yayınları) Bedri Rahmi Eyuboğlu'nun “Türküler Dolusu” şiirine yer verilmiş olması dikkat çekicidir. Oysaki bu şiir dışında kültürel değerlerimizi öğrencilere aktarabileceğimiz başka şiirler de vardır. Yine "Toplum Hayatı" teması için iki farklı yayında (Bisiklet ve Enderun Yayınları) Mehmet Salihoğlu'nun "Birlikte" adlı şiirine rastlanır. "Atatürk" teması için ise iki farklı yayında (Enderun ve Koza) Cahit Külebi'nin "Atatürk Kurtuluş Savaşında" şiirinin tercih edildiği görülmüştür. Farklı yayınlarda aynı temayı aynı şiirle sunmaktansa o temayı yansıtacak başka örneklerin bulunmasının daha yerinde ve doğru olacağını düşünülmektedir.

Türkçe dersi $(6,7,8$. sınıflar) öğretim programında "Şiir türündeki metinler öğrenci seviyesine uygun, şiir dilinin özelliklerini yansıtan, sözvarlığını zenginleştiren, türünün güzel örneklerinden seçilmelidir" (2006: 56) ifadesi yer alır. Ayrıca program, şiirlerin bütün hâlinde alınmasını esas kılar. Şiirlerin parça bütünlüğünü bozmak, okuyucuya/dinleyiciye eksik ya da yanlış ileti verebileceği gibi şiirin mevcut estetik ve ritmine de zarar verir. Üç yayında da yer alan "Türküler Dolusu" şiirinin yalnızca Enderun yayınlarında tam metnine yer verdiği görülmüştür. Millî Eğitim yayınlarında serbest okuma metni olarak yer alan Orhan Veli Kanık’ın “istanbul’u Dinliyorum” şiirinde ise altı dizenin çıkarıldığı tespit edilmiştir.

Çalışmanın son alt problemi "8. Sınıf Türkçe ders kitaplarında en çok tercih edilen şiir türü hangisidir?" şeklindedir. Kesin bir ayrım olmamasına rağmen şiirler konularına göre beş türe ayrılır: didaktik, epik, lirik, pastoral ve satirik. Kitaplardaki şiirler türlerine göre sınıflandırıldığında aşağıdaki tabloya ulaşabilir:

Tablo 5: Şiirlerin Türlere Göre Dağılımı

\begin{tabular}{ccccccc}
\hline & Didaktik & Epik & Lirik & Pastoral & Satirik & Toplam \\
\hline F & 2 & 5 & 13 & 2 & 1 & 23 \\
$\%$ & 8,7 & 21,7 & 56,5 & 8,7 & 4,3 & 100,0 \\
\hline
\end{tabular}

Tablo 5 incelendiğinde, 8.sınıf Türkçe ders kitaplarında yer alan şiirlerin \%56,5 gibi büyük bir oranının lirik şiirler olduğu gözlenmektedir. En az tercih edilen şiir türü ise \%4,3'lük oranıyla satirik şiir olmuştur. Kitaplarda farklı türlerden şiirlere yer vermenin öğrencilerin şiir metinlerini daha iyi kavrayabilmesi ve anlamlandırabilmesi için faydalı olacağı düşünülmektedir. 


\section{Sonuç ve Öneriler}

1. 8. Sınıf Türkçe ders kitaplardaki tüm metinlere oranla Millî Eğitim yayınlarında $3 / 37(\% 8,1)$, Bisiklet yayınlarında 5/37 (\%13,5), Enderun yayınlarında 10/43 $(\% 23,2)$ ve Koza yayınlarında 9/36 (\%25) şiir metninin yer aldığı sonucuna ulaşılmıştır. Ders kitaplarında yer verilen şiir metinlerinin sayısı artırılmalı, öğrenciler şiirin farklı biçim ve türleriyle daha çok karşılaştırılmalıdır.

2. Kitaplardaki şiirler şekil yönünden incelendiğinde hem serbest hem ölçülü ve uyaklı şiir örneklerine yer verildiği görülmüştür. Öğrencilere söz sanatlarını kavratmak için kullanılabilecek şiirler de mevcuttur. Ancak kafiye, redif gibi şiire ahenk katan unsurların sezdirilebilmesi için daha etkili örnekler tercih edilebilir.

Şiir metinleri bir bütün olarak ele alınır ve o şekilde değerlendirilir. Kitaplarda yer alan şiirlerin eksiltilmesi ya da kısaltılması uygun değildir.

3. Şiirler temaları açııından değerlendirildiğinde farklı yayınevlerine ait kitaplarda birkaç temada ortak şiirler tespit edilmiştir. Ders kitaplarında öğrencilerin ilgi ve seviyeleri göz önünde bulundurularak edebiyatımızın seçkin isimlerinden yeni şiirlere yer verilebilir. "Bilim ve Teknoloji" ve “iletişim” gibi temalar da şiir metinleriyle desteklenebilir.

4. Kitaplarda en çok yer verilen şiir türünün lirik şiir olduğu sonucuna ulaşılmıştır. Öğrencilerin şiiri tek yönlü düşünmelerini engellemek için farklı türlerdeki örneklerin artırılması gerektiği söylenebilir.

\section{Kaynakça}

\section{A. İncelemeye Esas Olan Kaynaklar}

Altan, A., Arhan, S., Başar, S., Öztürker, G. ve Yılmaz, D. (2012a). ilköğretim Türkçe 8 ders kitabı. Ankara: Millî Eğitim Bakanlığı Yayınları.

Altan, A., Arhan, S., Başar, S., Öztürker, G. ve Yılmaz, D. (2012b). ilköğretim Türkçe 8 öğretmen kılavuz kitabı. Ankara: Millî Eğitim Bakanlığı Yayınları.

Kapulu, A. ve Karaca, A. (2010a). Ilköğretim Türkçe 8 ders kitabı. Ankara: Koza Yayın Dağıtım.

Kapulu, A. ve Karaca, A. (2010b). Ilköğretim Türkçe 8 öğretmen kılavuz kitabı. Ankara: Koza Yayın Dağıtım.

Kurt, M., Altay, J. ve Kara, M. (2012a). Ilköğretim Türkçe ders kitabı 8. Ankara: Enderun Matbaacılık.

Kurt, M., Altay, J. ve Kara, M. (2012b). Ilköğretim Türkçe öğretmen kılavuz kitabı 8. Ankara: Enderun Matbaacilık.

Şahin, D. (2012a). Ilköğretim Türkçe ders kitabı 8. Ankara: Bisiklet Yayıncılık.

Şahin, D. (2012b). ilköğretim Türkçe öğretmen kılavuz kitabı 8. Ankara: Bisiklet Yayıncılık. 


\section{Sınıf Türkçe Ders Kitaplarındaki Şiirlerin Şekil, Tema ve Tür Açılarından İncelenmesi}

\section{B. Diğer Kaynaklar}

Aksan, D. (1999). Şiir dili ve Türk şiir dili (3. Baskı). Ankara: Engin Yayınevi.

Akyol, H. (2006). Türkçe öğretim yöntemleri. Ankara: Kök Yayıncılık.

Cemiloğlu, M. (2001). Illköğretim okullarında Türkçe öğretimi (3. Baskı). İstanbul: Alfa Yayınları.

Çetin, N. (2003). Şiir çözümleme yöntemi. Ankara: Öncü Basımevi.

Karaalioğlu, S. K. (1966). Türk şiir sanatı. İstanbul: İnkılap ve Aka Kitabevleri.

Kavcar, C., Oğuzkan, F. ve Sever, S. (1995). Türkçe öğretimi. Ankara: Engin Yayınevi.

Kavcar, C. ve Oğuzkan, A. F. (1999). Örnek edebi metinlerle yazılı ve sözlü anlatım. Ankara: Anı Yayıncılık.

Millî Eğitim Bakanlığı. (2006). Illköğretim Türkçe dersi (6, 7, 8. sınıflar) öğretim programı. Ankara: Millî Eğitim Bakanlığı Yayınları.

Millî Eğitim Bakanlığı. (2009). Ilköğretim Türkçe dersi öğretim programı ve kılavuzu (1-5. Sınıflar). Ankara: Millî Eğitim Bakanlığı Yayınları.

Oğuzkan, A.F. (2010). Çocuk edebiyatı (9. Baskı). Ankara: Anı Yayıncılık.

Özbay, M. (2009). Anlama teknikleri: I Okuma eğitimi. Ankara: Öncü Kitap.

Özdemir, E. (1983). Anadili Öğretimi. Türk Dili (Dil Öğretimi Özel Sayısı) (379-380), 18-30.

Ünalan, Ş. (2001). Türkçe öğretimi (2. Basım). Ankara: Nobel Yayın Dağıtım.

Yalçın, A. ve Aytaş, G. (2005). Çocuk edebiyatı (3. Baskı). Ankara: Akçağ Yayınları.

Yıldırım, A. ve Şimşek, H. (2011). Sosyal bilimlerde nitel araştırma yöntemleri (8. Baskı). Ankara: Seçkin Yayıncilık. 